\title{
HOUSING POVERTY IN POLISH HOUSEHOLDS AND ITS DIVERSITY
}

\author{
Paweł Ulman, Ph.D., Associate Professor ${ }^{1}$ \\ Małgorzata Ćwiek, Ph.D. ${ }^{2}$ \\ Cracow University of Economics \\ College of Economics, Finance and Law \\ Department of Statistics \\ 27 Rakowicka St., 31-510 Cracow, Poland \\ ${ }^{1}$ e-mail: pawel.ulman@uek.krakow.pl \\ ORCID: 0000-0002-1911-8821 \\ 2 e-mail: malgorzata.cwiek@uek.krakow.pl \\ ORCID: 0000-0002-6375-098X
}

Received 30 October 2019, Accepted 30 March 2020

\begin{abstract}
Research background: The European Housing Charter defines housing as a basic necessity, but also a fundamental social right underpinning the European social model as well as an element of human dignity. Housing conditions constitute a major element of the broader quality of life for individuals and society.

Purpose: The aim of this paper is to assess the level of housing poverty in general and in selected areas of an assessment of Polish households due to the selected socio-demographic characteristics of the respondent or household.

Research methodology: The study was conducted on the basis of micro-data from the Household Budget Survey of 2017. To determine the housing poverty risk for each household the Integrated Fuzzy and Relative approach was used, which allows for the aggregation of symptoms measured on different measuring scales into the one risk assessment of poor housing conditions. This assessment, overall and in specific areas of housing poverty, became the basis for the study of the factors differentiating this kind of poverty. For this purpose, regression trees were used.

Results: The greatest risk of housing poverty was observed in households living in rural areas, in families with many children, in the households of single mothers or fathers, as well as in households living on unearned sources of income.

Novelty: The use of the Integrated Fuzzy and Relative approach for housing poverty research is an innovative approach and is applied in the paper.
\end{abstract}

Keywords: housing poverty, housing in Poland, Integrated Fuzzy and Relative, fuzzy set 


\section{Introduction}

A home is one of the fundamental needs of an individual, and it is also the basis for the functioning of a household. The World Health Organization defines housing as 'the residential environment, neighborhood, micro district or psychical structure that mankind uses for shelter, and the environments of that structure, including all necessary services, facilities, equipment and devices, needed for the physical health and social well-being of the family and the individual' (World Health Organization 1961). The importance of adequate housing is highlighted in the Universal Declaration of Human Rights (1948), Article 25: 'Everyone has the right to a standard of living adequate for the health and well-being of himself and of his family, including food, clothing, housing and medical care and necessary social services...'

Housing serves a full range of functions, which include: protective functions, biological functions, social functions, humanistic functions, cultural and educational functions and economic functions (Tyrell, Tuppett 2017).

The inability to meet housing needs at an appropriate level results in housing poverty (Kozera, Stanisławska, Głowicka-Wołoszyn, 2017; Kurowski, Broda-Wysocki, 2017; Stephens, van Steen, 2011). To measure the level of housing poverty it is necessary to define the minimum housing standard that must be met. Objective and subjective measures of poor financial situation should be distinguished. The most common objective measures for living condition quality are the overcrowding rate and the housing cost overburden rate. The overcrowding rate is an indicator of space-related problems, which measures the proportion of people living in an overcrowded dwelling as defined by the number of rooms available in the household, household size, and the members' age and family situation (Eurostat, 2018). A subjective perception of housing quality may be as substantial for individuals and households as an objective outlook (Sunega, Lux, 2016). Housing deprivation consists in the inability in the respondent's opinion to provide ordinary living conditions common to the majority of society (Rakauskienè, Volodzkienè, 2017). Indicators of poor housing condition include a leaking roof, damp walls/floors/foundations, or rotting window frames or floors; a lack of bath or shower facilities in the dwelling; a lack of an indoor flush toilet for the sole use of the household; and a lack of adequate light (Eurostat, 2018; Borg, 2015).

According to the definition provided by the Polish Central Statistical Office, a housing unit consists of one or more rooms together with auxiliary rooms, built or rebuilt for residential purposes, structurally separated (with permanent walls) within a building, with an independent entrance leading from a staircase, a general corridor, a common hallway or directly from a street, 
courtyard, or garden (GUS, 2018, p. 14). The current housing situation in Poland is largely due to historical factors. The destruction of the World Wars and the shortage of funds allocated for housing policy in the years 1945-1989 caused a chronic shortage of housing units. The freeing of the housing market after 1989 has resulted in stratification in the quality of housing standards. Currently, we are still dealing with a housing deficit in Poland. In 2017 there was an average of 376 housing units per each 1,000 of the population. The average housing unit had an area of $74 \mathrm{~m}^{2}$ and consisted of less than 4 rooms. One housing unit accounted for an average of 2.66 persons and one room for 0.7 people. In 2018, the number of dwellings increased by 175 thousand compared to the previous year, resulting in an increase of $1.2 \%$. In 2018 , there was also a slight improvement in the quality of housing in relation to the previous year. The average square footage increased by $0.2 \mathrm{~m}^{2}$, the average usable floor per person grew by $0.4 \mathrm{~m}^{2}$, and the average number of people per room fell by 0.01 (GUS, 2019).

Despite the observed increase in the number of housing units in Poland, the problem of overcrowding measured by the so-called overcrowding rate is very serious. According to Eurostat data, the percentage of the population living in overcrowded dwellings in Poland is very high at 40\% (https://ec.europa.eu/eurostat/web/income-and-living-conditions/data/maintables). The situation is worse only in Bulgaria, Romania and Latvia. The rate of overcrowding in Poland is about 25 p.p. higher than the average for the European Union. For comparison, in countries such as Ireland, Cyprus, Malta and the United Kingdom, the problem of living in overcrowded dwellings affects less than $5 \%$ of the population.

Due to the multiplicity of functions that housing performs in the life of an individual and a household, it should be stated that housing conditions constitute an important element of the standard and quality of life of the population. Therefore, the ability and manner of satisfying housing needs are of interest to housing policy makers (Hanratty, 2017; Fahey, Norris, 2010). Housing policy is an element of social policy and its aim is to equalize opportunities by providing access to social housing (Hansson, Lundgren, 2019). This purpose should be achieved not by giving citizens ready-made instructions in making decisions aiming to ensure a decent place to live in, but rather by creating general economic conditions conducive to such a process. The selection of appropriate tools for the implementation of housing policy depends on the access to full and reliable information on the housing conditions of particular socioeconomic groups. The aim of this paper is to assess (in the multidimensional approach) the level of housing poverty risk of Polish households in general and in selected areas of assessment due to the selected socio demographic characteristics of the respondent or household. 
There are many scientific papers discussing on the one hand the need and the use of a multidimensional description of complex socio-economic phenomena on the other. The multidimensional approach to assessing the economic status of the surveyed units (individuals, households and countries) in the context of inequality and social welfare was indicated by, among others, S.C. Kolm (1977), A.B. Atkinson and F. Bourguignon (1982), E. Maasoumi (1986), K.Y. Tsui (1995, 1999), J.A. Weymark (2006), D. Aristei and B. Bracalente (2011). A multidimensional perspective is often used in poverty research. However, the classic method of identifying poverty is based on a unidimensional approach using data on income or expenditure for which a threshold value is determined. It allows classifying the examined units to the group of the poor or the non-poor in accordance with the concept of a crisp set (Alkire et al., 2015).

Another approach to capture poverty in its multidimensional perspective is based on the fuzzy set theory originally proposed by L.A. Zadeh (1965). A. Cerioli and S. Zani (1990) were the first to introduce this concept into the analysis of poverty in the multidimensional approach. Next it was developed by B. Cheli and A. Lemmi (1995) as the Totally Fuzzy and Relative (TFR) approach and later the Integrated Fuzzy and Relative (IFR) approach by, e.g. Betti and Verma (2008). Many other researchers have used these approaches to study the problem of poverty - E. Chiappero Martinetti (1994), J. Silber (2011) and Betti et al. (2015); to study the quality of life - G. Betti, R. Soldi, I. Talev (2016), G. Betti (2016) and H. Dudek and W. Szczesny (2017); for evaluating of housing poverty - P. Ulman and M. Ćwiek (2020); for labour market research B. Belhadj (2014) and F. De Battisti, D. Marasini, G. Nicolini (2015).

In this paper, we use the IFR (Integrated Fuzzy and Relative) approach proposed by G. Betti, B. Cheli, A. Lemmi, and V. Verma (2006) in the order to assess the level of housing poverty in Poland. This approach to assessing the quality of housing (housing poverty) is a kind of rarity among papers dealing with issues of broadly understood housing.

\section{Method and statistical data}

In order to analyze the housing poverty of households in Poland, micro-data from a representative Household Budget Survey conducted by the Central Statistical Office in Poland in 2017 were used. In recent times, the range of information collected on housing conditions in which a Polish household functions has been definitely expanded. Due to the fact that the thematic scope of this study includes such aspects of household life as income and expenditure, the intake of food, durable goods, the characteristics of household members (including their 
professional activity), and a subjective assessment of their financial situation, it is possible to make a wide analysis of housing conditions in conjunction with other household characteristics.

The data set for 2017 consists of 36,655 observations of households. Data about each household were obtained for a period of one month, which may cause the variability of some household characteristics (e.g. income or the situation of household members on the labor market) for more than one month, during which the housing situation of such a household has not changed. Assuming, however, that the aforementioned variation is random and not frequent so in a statistical approach it should not significantly affect the results of the survey of the determinants of housing poverty in Poland. Undoubtedly, a dwelling satisfies the basic needs of every human being as well as that having one and its standard is an important factor shaping the decisions and behavior of people in the socioeconomic sphere. From this follows the importance of the state's housing policy based on reliable diagnosis and evaluation in at least the context of the efficiency and effectiveness of the policy.

The said data set includes several variables describing the broadly understood housing situation of the households surveyed. On that basis, five areas were identified: building standard (1), housing conditions (2), objective standard of the dwelling (3), subjective standard of the dwelling (4), and the surroundings (5). The first area (building standard) included the following variables: type of building, subjective evaluation of the standard of the building, and the security of the building. The second area (housing conditions), involved: whether the household shares the dwelling with another, square footage per person, number of rooms per person, and whether the dwelling is too small or too large for the household's needs. In the third area (objective standard of the dwelling), the following variables were considered: whether there is a kitchen, a water supply system, a bathroom, a flushable toilet, whether the toilet is a separate room, whether there is hot running water, a heating system, and whether there is a balcony, terrace or garden. In the fourth area (subjective standard of the dwelling): whether the water supply system meets the needs of the household, similarly for plumbing, whether the roof leaks or the walls are damp, whether the apartment is too dark, is it warm enough in winter, and cool enough in the summer. The fifth area (surroundings) considered: a noisy environment, burdensome pollution, the danger of crime, or whether the dwelling is located in an area with poor infrastructure.

The above-mentioned variables were obtained by measuring using at least an ordinal scale $^{1}$. In order to aggregate these variables, we used the IFR (Integrated Fuzzy and Relative)

\footnotetext{
${ }^{1}$ It is important to specify order for each variable, including dichotomous variables, due to the quality of residence. For example, for the variable "whether the toilet is in a separate room", an affirmative answer indicates the better quality of the dwelling than a negative answer.
} 
approach proposed and developed by A. Cerioli and S. Zani (1990), B. Cheli (1995), G. Betti, B. Cheli, A. Lemmi and V. Verma (2006).

The basis for aggregating the symptoms of poor housing situation represented by the above-mentioned variables is the cumulative distribution function, on the basis of which a measure of the risk of poor housing situation due to a given symptom is determined for each unit, each variable in a given area:

$$
e_{h j, i}=\frac{1-F\left(c_{h j, i}\right)}{1-F(1)}, h=1,2, \ldots, m ; j=1,2, \ldots, k ; i=1,2, \ldots, n
$$

where:

$c_{h j, i}-$ variant rank of the $j$-variable (poor housing condition symptom) of the $h$-area of housing situation for the $i$-household,

$F(1)-j$-variable value distribution of the $h$-area of the housing situation for the lowest value of this variable (a variant of the $j$-variable relating to the worst housing situation).

Formula (1) makes it possible to harmonize the variation range of each variable by normalizing them within the interval $[0 ; 1]$, which in turn gives rise to the aggregation of the individual symptoms of poor housing resulting in a single measure. For this purpose, the following formula may be used:

$$
e_{h, i}=\frac{\sum_{j=1}^{k_{h}} w_{h j}\left(1-e_{h j, i}\right)}{\sum_{j=1}^{k_{h}} w_{h j}}, h=1,2, \ldots, m ; i=1,2, \ldots, n
$$

where $w_{h j}$ is the weight of the $j$-the symptom of housing poverty.

In socio-economic surveys, the weight system can be determined by a statistical analysis or by expert opinion. If we have no indication as to the expert opinions on the weights reflecting the importance of this symptom it is possible, in the second approach, to use the weights, the values of which are determined empirically. G. Betti and V. Verma (1999) proposed a weighting system that takes into account the discriminant and their information capacity. Discriminant capacity are most often assessed by measuring the variation level of the variable, while the information capacity is measured on the basis of the level of the given variable's (symptom's) correlation with all the other variables. The said system of weights can thus be expressed as follows: 


$$
w_{h j}=w_{h j}^{a} \cdot w_{h j}^{b}, h=1,2, \ldots, m ; j=1,2, \ldots, k_{h}
$$

where:

$w_{h j}^{a}$ - measure of the information level of the $j$-th variable (symptom) in the $h$-th area,

$w_{h j}^{b}--$ measure of the discriminatory capacity of the $j$-th variable (symptom) in the $h$-th area.

Defining weights based on individual correlated symptoms is performed to favor most of these variables (symptoms) that are at least correlated with some other variables, and vice versa, the least rewarded are those with the highest correlation. Applying the following formula implements this requirement:

$$
w_{h j}^{a}=\left[\frac{1}{1+\sum_{j^{\prime}=1}^{k_{h}}\left|r_{e_{h j, h^{\prime}}}\right| r_{e_{h j, h h^{\prime}}}<r_{e_{h j}}^{*}}\right]\left[\frac{1}{\sum_{j^{\prime}=1}^{k_{h}}\left|r_{e_{h j, h j^{\prime}} \mid}\right| r_{e_{h j, h j^{\prime}}} \geq r_{e_{h j}}^{*}}\right], j, j^{\prime}=1,2, \ldots, k_{h} ; h=1,2, \ldots, m
$$

where:

$r_{e_{h j, h j^{\prime}}}-$ correlation coefficient of vulnerability to housing poverty corresponding to $j$-th and $j$ '-th symptom in the $h$-th area,

$r_{e_{h j}}^{*}-$ threshold value of the correlation coefficient of vulnerability to poor housing due to the $j$-th symptom in the $h$-th area that can be evaluated as follows: $r_{e_{h j}}^{*}=\min _{j} \max _{j^{\prime}}\left|r_{e_{h j, j^{\prime}}}\right|, j, j^{\prime}=1,2, \ldots, k_{h} ; j \neq j^{\prime}$.

The values of weights $w_{h j}^{a}$ were calculated for each symptom separately in each of the aforementioned areas, eventually producing the square root of formula 4 . Such a procedure was the result of obtaining, in the case of two variables, relatively large values of the weights $w_{h j}^{a}$, which resulted in the marginalization of the impact of other variables on the assessment of vulnerability to poor housing in a given area.

The following was adopted as a measure of the ability to discriminate:

$$
w_{h j}^{b}=\frac{S\left(e_{h j}\right)}{1-\overline{e_{h j}}}, h=1,2, \ldots, m ; j=1,2, \ldots, k_{h}
$$

where $S\left(e_{h j}\right)$ and $\overline{e_{h j}}$ are, respectively, the standard deviation, and the average assessment of vulnerability to poor housing due to the $j$-th symptom in the $h$-th area. 
In the next step, the aggregation of ratings indicating no risk of poor housing in individual areas into a single synthetic assessment determined for each household was performed in the following way:

$$
e_{i}=\frac{\sum_{h=1}^{m} e_{h, i}}{m}, i=1,2, \ldots, n
$$

Finally, for each household, the function of belonging to a sphere of housing poverty is calculated according to the formula:

$$
\lambda_{i}=\left(1-F_{i}\right)^{\alpha-1}\left(1-L_{i}\right), i=1,2, \ldots, n
$$

where: $F_{i}$ and $L_{i}$ is the value of, respectively, cumulative distribution and the Lorenz function assigned for ratings of the absence of vulnerability to poor housing $\left(\mathrm{e}_{\mathrm{i}}\right)$ and $\alpha$ is a parameter (Panek, 2010).

Parameter $\alpha$ allowed us to calibrate function (7) in a particular situation so that the average value was equal to the value of the share of households at risk of housing poverty in the number of households in total, determined in a classic manner. This would imply the need to identify such households, which is not easy to do without special research in this field. In the absence of such information, it can be assumed that $\alpha=2$. $^{2}$

At present, statistics provide many possibilities for studying multidimensional relationships. In this paper it was decided to use regression trees. They are one of the methods of data mining allowing for a recursive division of the set of observations into disjoint subsets based on a dependent variable, which is measured at least on an interval scale (Lapczyński, 2010, p. 70). Ultimately, the point is to separate the high and low values of the dependent variable at each stage of the split, while minimizing variation of leaf. The most commonly used distribution rules are variance or average deviation.

The model for classification and regression trees is created locally by submitting models built in disjoint segments of multidimensional variable space:

$$
f\left(x_{i}\right)=\sum_{k=1}^{K} \alpha_{k} I\left(x_{i} \in R_{k}\right)
$$

where:

$$
R_{k}-\text { subspaces (segments) of space } X^{m},
$$

\footnotetext{
2 The increase in the value of parameter $\alpha$ is associated with giving greater weight to households in a worse housing situation.
} 
$\alpha_{k}-$ model parameters,

$m$ - the number of explanatory variables and $I \mathrm{~s}$ the indicator variable given by the formula:

$$
I\left(x_{i} \in R_{k}\right)=\prod_{l=1}^{L} I\left(v_{k l}^{(d)} \leq x_{i l} \leq v_{k l}^{(g)}\right)
$$

where $v_{k l}^{(d)}$ and $v_{k l}^{(g)}$ mean the lower and upper limits respectively in $l$ dimension of space.

In the case of regression trees (when the dependent variable is measured on a strong scale) $\alpha_{k}$ are determined according to the formula:

$$
\alpha_{k}=\frac{1}{N(k)} \sum_{x_{i} \in R_{k}} y_{i}
$$

where $N(k)$ is the number of observations that belong to the segment $R_{k}$.

Next, the $R$ subspace should be divided into segments using the appropriate quality functions of division. Then, the optimal form of the model is selected using one of the edge trimming methods. More on classification and regression trees can be found in L. Breiman, J. Friedman, J.C. Stone, R.A. Olshen (1998), M. Walesiak, E. Gatnar (2012).

The C\&RT algorithm implemented in Statistica was used to build regression trees. In this algorithm, the trees obtained in the sequence are nested, i.e. they are truncated sequentially and contain all the nodes of the next smaller tree. Initially, when moving from one to the next, smaller tree, many nodes are often "pruned", but when approaching the root, fewer nodes are "pruned". The minimum cost of a cross-check (Ripley, 1996) was used to select a tree from a sequence.

\section{Housing poverty risk in Poland and its diversity}

In order to assess the housing poverty of individual households, the function of belonging to the sphere of poverty (7) was used. In the most frequently used approach, the values of this function are the basis for the aggregate calculation of housing poverty risk indicators. The most popular of these is the arithmetic or weighted average, which is an analogue of the poverty rate in the classic approach to poverty analysis. The calculation of the aforementioned average for the general population of households and in particular for the distinguished socioeconomic subgroups of these households allows to determinate the differences in the degree of housing 
poverty risk between these groups and further identifies the factors affecting the level of the said poverty. In addition, the housing poverty risk assessment calculated for each household makes it possible to apply multidimensional statistics methods to study the diversity of housing poverty and any factors affecting it.

The average value of the function of belonging to the sphere of housing poverty for the total number of households in Poland was 0.353 in 2017. Remembering that the function of belonging to the sphere of poverty takes values from 0 to 1 , the obtained result shows that the intensity of housing poverty (measured in a multidimensional approach) is not high. However, this result should not be interpreted in the context of the share of poor households in the total number of households. Similar calculations can be made for individual areas of housing poverty assessment. Within the five selected areas, the highest average range can be observed for the second area describing housing conditions and amounts to 0.386 , while the lowest one applies to the fifth area defining the residential environment, with the value of 0.171 . The average value of the housing poverty risk range applies to the other areas, i.e., standard of the building, objective and subjective housing unit standard and amounts to $0.317,0.331$, and 0.212 , respectively. Similar calculations can be made in various socio-economic cross-sections of the examined household population. The average values of the function of belonging to the sphere of housing poverty in terms of: region of living, domicile, biological household type and socioeconomic group are presented in Figure 1.

Among the selected regions, the eastern part of the country stands out with its significantly lower average range of housing poverty risk than in the case of the other regions. This is all the more interesting that the east of Poland is generally considered to be its poorest part. On the other hand, people living in this area traditionally attach great importance to creating and maintaining the best possible living conditions for themselves. An interesting correlation was also observed in the case of the place of residence class and the household. The lowest average range of poor living conditions corresponds to the average sized cities (population of 200,000 499,000). A worse average housing situation was observed in both large cities (population over $500,000)$ and towns with a population of 100,000-199,000. On the other hand, the next place of residence class (population of 20,000-99,000) was characterized by a lower average range of housing poverty than cities and towns with 100,000-199,000 population and towns with less than 20,000 inhabitants. Determining what such a diversity of housing conditions results from requires further in-depth research. However, the absolutely largest average range of the risk of housing poverty was observed in rural areas. 

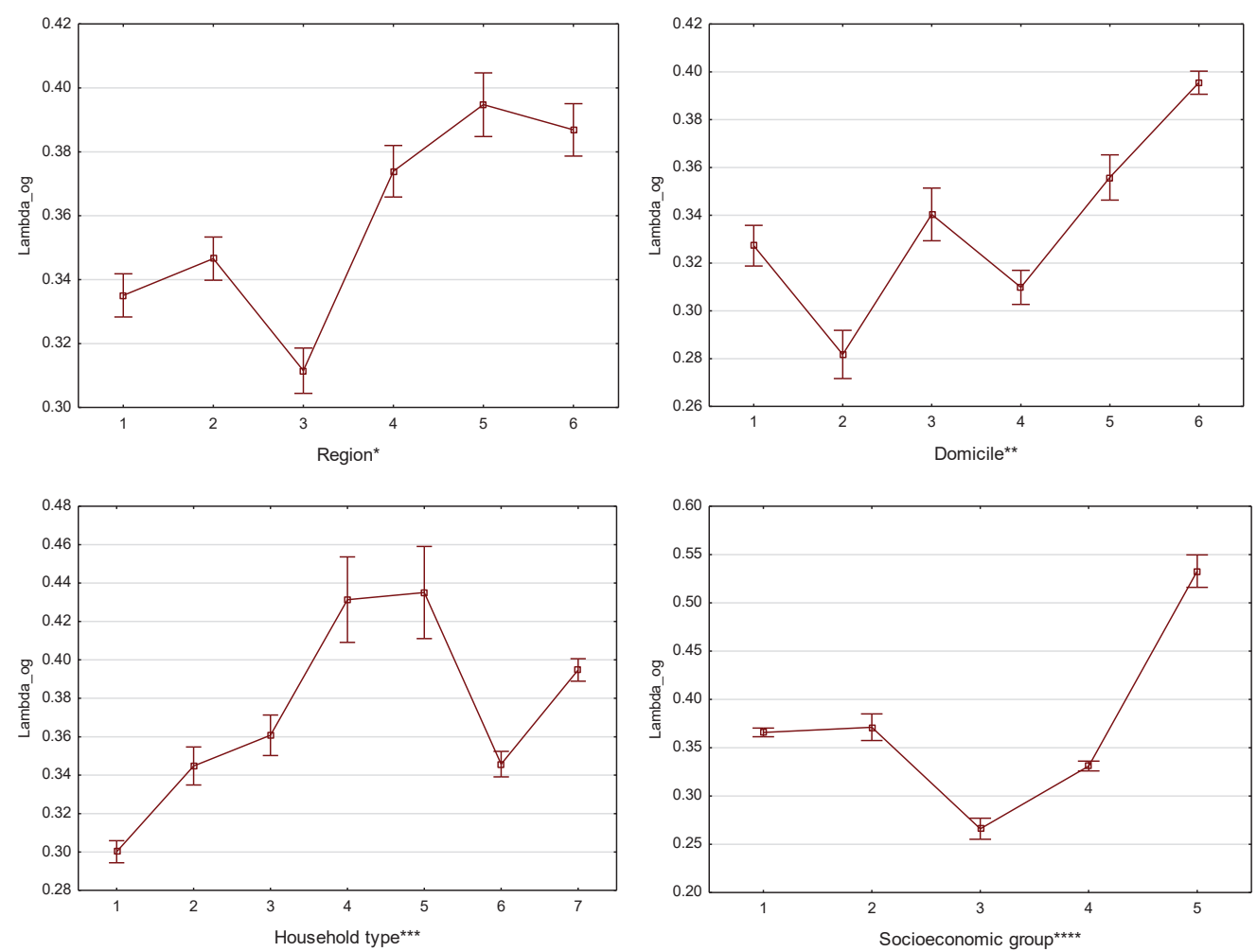

* Region: 1 - central, 2 - south, 3 - east, 4 - northwest, 5 - southwest, 6 - north; ${ }^{* *}$ Domicile 1 - 500,000 inhabitants or more, 2 - 200,000-499,000, 3 - 100,000-199,000, 4 - 20,000-99,000, 5 - less than 20,000, 6 - rural areas;

${ }^{* * *}$ Household type 1 - couple without children, 2 - couple with 1 child, 3 - couple with 2 children, 4 - couple with 3 or more children, 5 - single parent with 1 child, 6 - single-person household, 7 - others; ${ }^{* * * *}$ Socioeconomic group 1 - employees, 2 - farmers, 3 - self-employed, 4 - pensioners, 5 - household maintained from non-earned sources.

Figure 1. The average range of total housing poverty risk due to the characteristics of the selected households

Source: own calculations based on data from the Household Budget Survey of 2017.

Regarding the biological type of households, the highest average risk of housing poverty affects single parents as well as large families (with three or more children). The lowest average risk of poor housing conditions was observed in married couples living without children (these may be families without children at all or empty nesters where children had set up their own households).

The survey of households according to socio-economic group showed that the highest average risk of housing poverty can be observed in households living on unearned sources of income. On the other hand, there is no large difference between the average coverage of housing poverty risk in households of employees and farmers, which is a socio-economic 
group often characterized by low incomes. The lowest risk of poor housing was observed in the households of self-employed persons. It follows that the entrepreneurship that is needed to run one's own business also translates into better skills in the organization of good housing conditions. Of course, the fact that the average income in this social group is high is not without significance.

To study the impact of the all specified variables together on the level of the risk of housing poverty regression trees were used. The explained variable is the mean extent of housing poverty risk. The explanatory variables include: income per person, place of residence class, region, family type and socioeconomic group.

The trees were created for the extent of housing poverty risk in general and for individual areas; however, the paper contains only a graph for the risk of housing poverty in general. Due to the large size of the discussed tree, the graph was divided into two parts according to the first division line. The left part presents the range of housing poverty risk in general for households with income per person lower or equal to 1,371.58 PLN (Figure 2) and the right for households with income per person higher than 1,371.58 PLN (Figure 3).

The first line of coverage division in the analyzed regression tree indicates that households with income per capita higher than 1,371.58 PLN usually have a lower risk of housing poverty than households with income per capita equal to or lower than 1,371.58 PLN. Among households with lower income per capita, as a rule, a higher risk of housing poverty is observed among those living from nonprofit sources of income than among households belonging to the other socio-economic groups (cf. Figure 2). The next division line indicates that households with income per capita equal to or lower than 1,371.58 PLN, where the reference persons belong to the groups of employees, farmers, self-employed or retired located in the eastern part of the country, are characterized by a lower average extent of the poverty risk than households with the same characteristics but living in other regions. Further dividing lines indicate that the risk of housing poverty is differentiated by variables such as income per capita, the class of the place of residence in which the household is located and the socio-economic group.

Among households with income per capita higher than 1,371.58 PLN the next division line also concerns income per person. Interestingly, the average extent of housing poverty risk among households with income per person above 1,821.98 PLN is higher than for households with income below 1,821.98 PLN (cf. Figure 3). This may indicate that housing poverty is not always caused by monetary poverty. The subsequent division lines relate to the socioeconomic group, income per person (right side) and place of residence class (left side). 


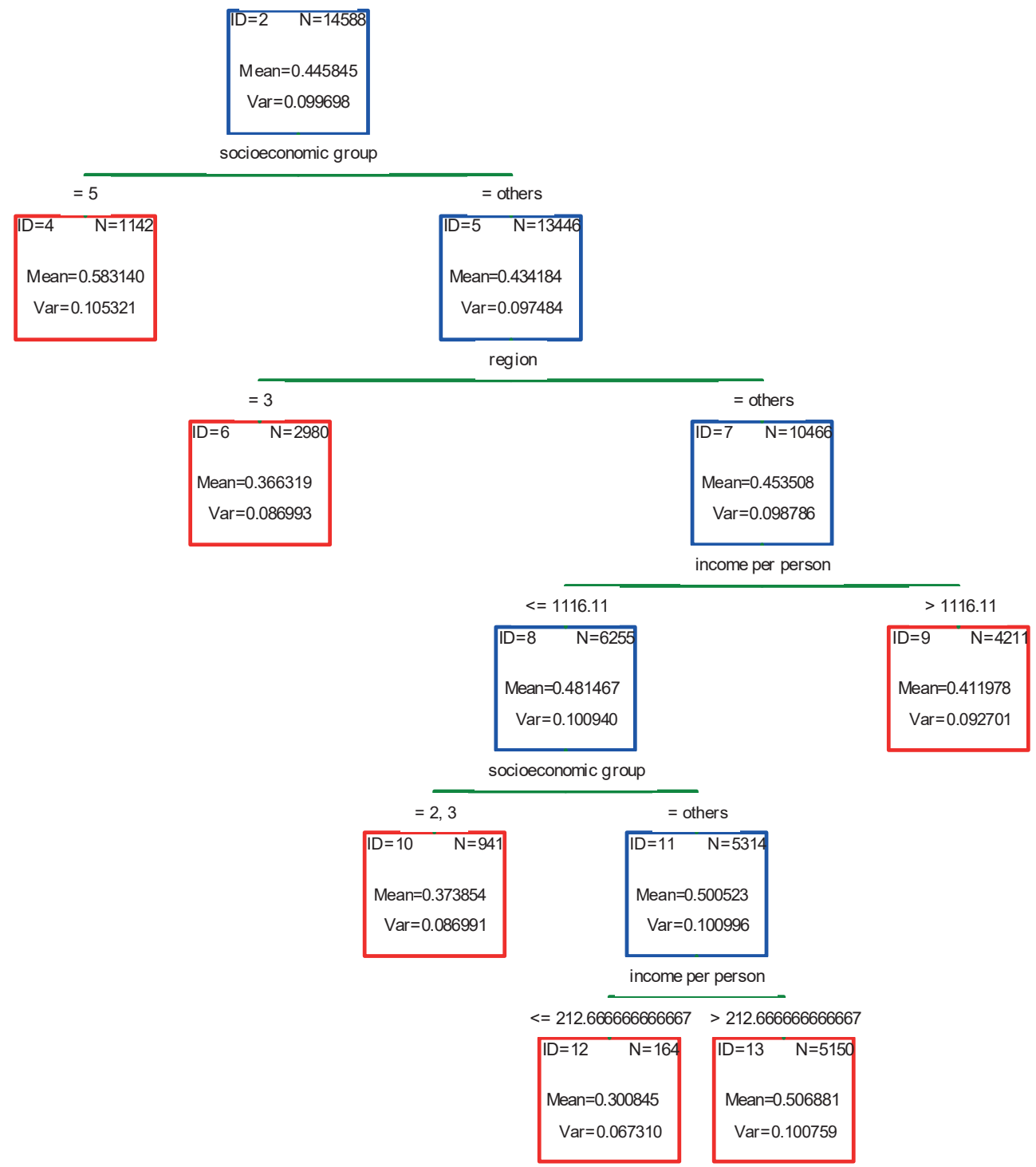

Figure 2. Left part of the regression tree for the extent of housing poverty risk in general for households with income per person lower or equal to 1,371.58 PLN

Source: own calculations based on data from the Household Budget Survey of 2017. 


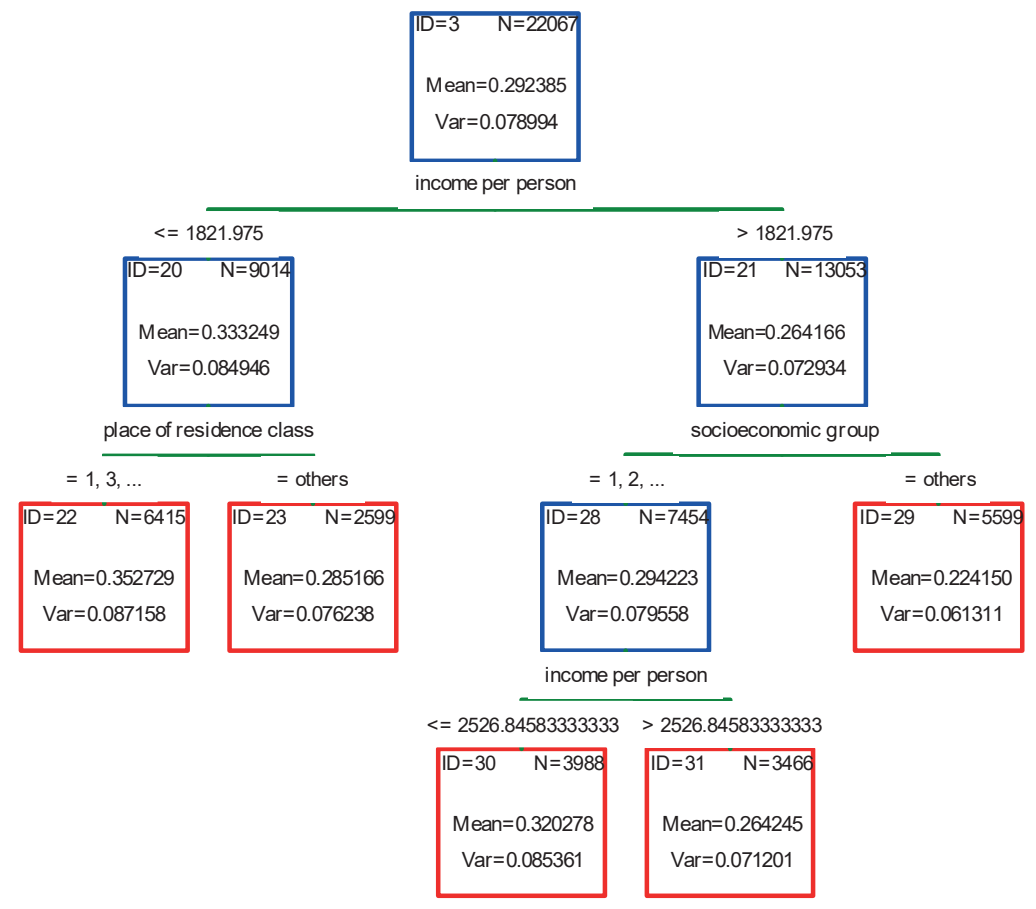

Figure 3. Right part of the regression tree for the extent of housing poverty risk in general for households with income per person higher than 1,371.58 PLN

Source: own calculations based on data from the Household Budget Survey of 2017.

The main dividing lines for individual areas of assessment are: place of residence class for 1 area (standard of the building), type of family for areas 2 and 3 (housing conditions and objective standard of the dwelling), socioeconomic group for area 4 (subjective standard of the dwelling) and region for area 5 (surroundings).

Table 1 presents the list of rankings obtained by particular explanatory variables in the regression trees for the risk of housing poverty in general and in particular areas.

Table 1. Ranks of explanatory variables in the regression trees of housing poverty risk in general and for particular areas

\begin{tabular}{|l|r|r|r|r|r|r|}
\hline \multirow{2}{*}{\multicolumn{1}{c|}{ Specification }} & \multirow{2}{*}{ Total } & \multicolumn{5}{c|}{ Area } \\
\cline { 3 - 8 } & & 1 & 2 & 3 & 4 & 5 \\
\hline \multicolumn{1}{|c}{1} & 2 & 3 & 4 & 5 & 6 & 7 \\
\hline Income per person & 100 & 100 & 46 & 100 & 93 & 47 \\
\hline Place of residence class & 33 & 86 & 21 & 27 & 100 & 100 \\
\hline Region & 31 & 41 & 5 & 46 & 59 & 74 \\
\hline
\end{tabular}




\begin{tabular}{|l|l|l|l|l|l|l|}
\hline \multicolumn{1}{|c|}{1} & 2 & 3 & 4 & 5 & 6 & 7 \\
\hline Family type & 27 & 41 & 100 & 49 & 91 & 33 \\
\hline Socioeconomic group & 48 & 34 & 58 & 64 & 93 & 31 \\
\hline
\end{tabular}

Source: own calculations based on data from the Household Budget Survey of 2017.

In the case of housing poverty risk in general, the largest contributor variable was income per capita. Although it might seem that income is the factor that will differentiate all separated areas of housing conditions to the greatest extent, this is not the case. For housing conditions (defined by the number of rooms per person, among other things), family type is the most discriminatory. For the areas of subjective standard of living and surroundings, the highest rank has been assigned to the place of residence class. For the area of surroundings, the region was also more important than the per capita income.

\section{Conclusions}

Housing is necessary to meet the physiological needs placed at the very bottom of Maslow's pyramid. It is also a means to meet all the higher-order needs such as security, belonging, recognition and self-realization. For this reason, it is very important to constantly monitor not only the housing stock but also the quality of it.

Application of the IFR approach to the study permitted the inclusion of a large number of quantitative and qualitative, as well as objective and subjective variables in the analysis. The study included symptoms indicating the poor housing situation of households in the following areas: standard of the building, housing conditions, objective and subjective housing standards, and housing environment. So far, there have been no studies on housing poverty in Poland using the IFR approach. Kozera et al. (2017) presented a synthetic meter constructed with the use of the Technique for Order Preference by Similarity to an Ideal Solution to identify and evaluate changes in housing poverty in the European Union. However, due to correlations between the variables, four of nine were removed. The weighting of variables applied in this study allowed to include a large number of variables, solving the problem of the correlation between them.

The greatest risk of housing poverty was observed in households living in rural areas, in families with many children, in the households of single mothers or fathers, as well as in households living on unearned sources of income. The application of regression trees to the study of housing poverty allowed us to distinguish sets of logical conditions describing the differentiation of the risk of poor housing. Income per capita was the most important variable 
explaining the risk of housing poverty in general and in the areas of building standard and objective housing standard. The most important explanatory variable for the threat of housing poverty in the area of the subjective standard of living and the housing environment turned out to be the place of residence class. In the area of housing conditions, the most important explanatory variable was the type of family. The different values of explanatory variables rank for particular areas confirms the different character of the separated areas, and thus the need for multidimensional research.

\section{Acknowledgements}

The study was financed from the funds granted to the Faculty of Management at Cracow University of Economics, within the framework of the subsidy for the maintenance of research potential.

\section{References}

Alkire, S., Foster, J.E., Seth, S., Santos, M.E., Roche, J.M., Ballon, P. (2015). Multidimensional Poverty Measurement and Analysis: Chapter 3 - Overview of Methods for Multidimensional Poverty Assessment, OPHI Working Paper No. 84.

Aristei, D., Bracalente, B. (2011). Measuring Multidimensional Inequality and Well-being: Methods and Empirical Applications to Italian Regions. Statistica, LXXI (2), 239-266.

Atkinson, A.B., Bourguignon, F. (1982). The Comparison of Multi-Dimensional Distributions of Economic Status. Review of Economic Studies, XLIX, 183-201.

Belhadj, B. (2014). Employment Measure in Development Countries via Minimum Wage and Poverty: New fuzzy approach. Opsearch, 52 (2), 329-339, DOI: 10.1007/s12597-0140176-3.

Betti, G. (2016). What Impact Has the Economic Crisis Had on Quality of Life in Europe? A Multidimensional and Fuzzy Approach. Quality and Quantity, 51 (1), 1-14. DOI: 10.1007/s11135-015-0308-8.

Betti, G., Cheli, B., Lemmi, A., Verma, V. (2006). On the Construction of Fuzzy Measures for the Analysis of Poverty and Social Exclusion. Statistica \& Applicazioni, 4 (1), 77-97.

Betti, G., Soldi, R., Talev, I. (2016). Fuzzy Multidimensional Indicators of Quality of Life: The Empirical Case of Macedonia. Social Indicators Research, 127 (1), 39-53. DOI: 10.1007/s11205-015-0965-y. 
Betti, G., Vetrma, V. (1999). Measuring the Degree of Poverty in a Dynamic and Comparative Context: A Multi-dimensional Approach Using Fuzzy Set Theory, Proceedings. ICCS-VI, 11, 289-301.

Betti, G., Verma, V. (2008). Fuzzy Measures of the Incidence of Relative Poverty and Deprivation: A Multi-dimensional Perspective. Statistical Methods \& Applications, 17 (2), 225-250. DOI 10.1007/s10260-007-0062-8.

Borg, I. (2015). Housing deprivation in Europe: On the role of rental tenure types. Housing, Theory and Society, 32 (1). 73-93. DOI: 10.1080/14036096.2014.969443.

Breiman, L., Friedman, J., Stone, J.C., Olshen, R.A. (1998). Classifications and Regression Trees. Chapman \&Hall.

Cerioli, A., Zani, S. (1990). A Fuzzy Approach to the Measurement of Poverty. In: C. Dagum (ed.), Income and Wealth Distribution, Inequality and Poverty. Berlin: Springer Verlag.

Cheli, B., Lemmi, A. (1995). Totally Fuzzy and Relative Approach to the Multidimensional Analysis of Poverty. Economics Notes, 24, 115-134.

Cheli, B. (1995). Totally Fuzzy and Relative Measures of Poverty in Dynamic Context. Metron, LIII (3-4), 183-205.

Chiappero Martinetti, E. (1994). A New Approach to Evaluation of Well-being and Poverty by Fuzzy Set Theory. Giornale degli Economisti e Annali di Economia, 53, 367-388.

De Battisti, F., Marasini, D., Nicolini, G. (2015). A Measure of Job Satisfaction by Means of Fuzzy Set Theory. Statistica Applicata - Italian Journal of Applied Statistics, 23 (3), 361-374.

Dudek, H., Szczęsny, W. (2017). Correlates of Multidimensional Indicator of Quality of Life Fractional Outcome Model Approach. Statistika, 97 (4), 46-61.

Eurostat (2018). Living conditions in Europe. Statistical book.

Fahey, T., Norris, M. (2010). Housing. In: F.G. Castles, S. Leibfried, J. Lewis, H. Obinger, C. Pierson (eds.), The oxford handbook of welfare state. Oxford-New York: Oxford University Press.

GUS (2018). Gospodarka mieszkaniowa w latach 2013-2017. Warszawa-Lublin. Retrieved from: http://stat.gov.pl/obszary-tematyczne/infrastruktura-komunalna-nieruchomosci (19.09.2019).

GUS (2019). Gospodarka mieszkaniowa w 2018 roku. Informacja sygnalna. Retrieved from: https://stat.gov.pl/obszary-tematyczne/infrastruktura-komunalna-nieruchomosci/nieruchomosci-budynki-infrastruktura-komunalna/gospodarka-mieszkaniowa-w-2018-roku,14,2.html (19.09.2019).

Hanratty, M. (2017). Do Local Economic Conditions Affect Homelessness? Impact of Area Housing Market Factors, Unemployment, and Poverty on Community Homeless Rates. Housing Policy Debate, 27 (4), 640-655. DOI: 10.1080/10511482.2017.1282885. 
Hansson, A.G., Lundgren, B. (2019). Defining Social Housing: A Discussion on the Suitable Criteria. Housing, Theory and Society, 36 (2), 149-166, DOI: 10.1080/14036096.2018.1459826.

https:/ec.europa.eu/eurostat/web/income-and-living-conditions/data/main-tables (19.09.2019).

Kolm, S.C. (1977). Multidimensional egalitarianism. Quarterly Journal of Economics, 91, 1-13.

Kozera, A., Stanisławska, J., Głowicka-Wołoszyn, R. (2017). Zjawisko ubóstwa mieszkaniowego w krajach Unii Europejskiej. Wiadomości Statystyczne, 1 (668), 77-89.

Kurowski, P., Broda-Wysocki, P. (2017). Ubóstwo mieszkaniowe: oblicza, trendy, wyzwania. Polityka Społeczna, 515 (2), 1-8.

Łapczyński, M. (2010). Drzewa klasyfikacyjne i regresyjne w badaniach marketingowych. Kraków: Wydawnictwo Uniwersytetu Ekonomicznego w Krakowie.

Maasoumi, E. (1986). The measurement and decomposition of Multidimensional Inequality. Econometrica, 54, 771-779.

Panek, T. (2010). Multidimensional Approach to Poverty Measurement: Fuzzy Measures of the Incidence and Depth of Poverty. Statistics in Transition 11 (2), 361-379.

Rakauskienè, O.G., Volodzkienè, L. (2017). The Inequality of Material Living Conditions in EU Countries. Economics and Sociology, 10 (1), 265-278. DOI: 10.14254/2071789X.2017/10-1/19.

Ripley, B.D. (1996). Pattern recognition and neural networks. Cambridge: Cambridge University Press.

Silber, J. (2011). Multidimensional Approach to Poverty Measurement: An Empirical Analysis of Poverty in Belgium, France, Germany, Italy and Spain, Based on the European Panel. Applied Economics, 43 (8), 951-961. DOI: 10.1080/00036840802600129.

Stephens, M., van Steen, G. (2011). 'Housing poverty' and income poverty in England and The Netherlands. Housing Studies, 26, 7-8, 1035-1057. DOI:10.1080/02673037.2011.6 15146.

Sunega, P., Lux, M. (2016). Subjective perception versus objective indicators of overcrowding and housing affordability. Journal of Housing and the Built Environment, 31, 695-717. DOI: 10.1007/s10901-016-9496-3.

The Universal Declaration of Human Rights (1948), the United Nations. Retrieved from: https:// www.jus.uio.no/lm/en/pdf/un.universal.declaration.of.human.rights.1948.portrait.letter. pdf (19.09.2019).

Tsui, K.Y. (1995). Multidimensional Generalizations of the Relative and Absolute Inequality Indices: The Atkinson-Kolm-Sen Approach. Journal of Economic Theory, 67, 251-265.

Tsui, K.Y. (1999). Multidimensional Inequality and Multidimensional Generalized Entropy Measure: an axiomatic derivation. Social Choice and Welfare, 16, 145-157. 
Tyrell, F.A., Tuppett, M.Y. (2017). A Growth Curve Analysis of Housing Quality among Transition-Aged Foster Youth. Child Youth Care Forum, 56, 91-117, DOI. 10.1007/s10566016-9370-1.

Ulman, P., Ćwiek, M. (2020). Measuring housing poverty in Poland: a multidimensional analysis. Housing Studies. DOI: 10.1080/02673037.2020.1759515.

Walesiak, M., Gatnar, E. (2012). Statystyczna analiza danych z wykorzystaniem programu R. Warszawa: Wydawnictwo Naukowe PWN.

Weymark, J.A. (2006). The Normative Approach to the Measurement pf Multidimensional Inequality. In: F. Farina, E. Savaglio, (eds.), Inequality and economic integration (pp. 303328). London: Routledge.

World Health Organization Technical Report Series (1961), No. 225.

Zadeh, L.A. (1965). Fuzzy set. Information and Control, 8 (3), 338-353. 